\title{
MAGMA INTRUSION IN 'PROTO-CALDERA CALDERA' SYSTEMS: EXAMPLE FROM THE NISYROS VOLCANO
}

\author{
Zouzias D. ${ }^{1}$, and St. Seymour K. ${ }^{2}$ \\ ${ }^{1}$ Department of Geology, University of Patras, Rion Patras 26500 GR, kstseymr@upatras.gr, \\ dizouzias@upatras.gr \\ ${ }^{2}$ Departments of Chemistry, Geography, Concordia University, Montreal H4B 1 R6 CA
}

\begin{abstract}
The interdependence of volcanism and tectonism has been focused upon in the last decade as a result of previously accumulated evidence, as well as, due to the application of remote sensing techniques in both these fields. Volcanoes depend on tectonic features such as faults for their positioning and operation and on petrotectonic environment for the chemistry of their magmas. Faults provide the plumbing system for magma ascent and therefore volcano localisation and distribution in space greatly depends on the tectonic pattern of an area. On the other hand, volcanoes locally imprint their volcanotectonic features such as radial and ring faults which result from cycles of magma replenishment (inflation) and evacuation (deflation) of magmatic reservoirs (magma chambers).

Under this light, the area in the easternmost extremity of the Aegean Arc is being reconsidered. Our main preliminary findings of ongoing research in the area, using field and remote sensing methods indicate localization of volcanic activity on Kos and on the Datca Peninsula of Asian Minor since Miocene due to the northbounding faults of the Datca Graben. Localisation of volcanic vents and calderas in the Kos-Nisyros area follows intersection of a major tectonic line of northnorthwesterly trending faults the 'Kos-Nisyros-Tilos Line' with $N 50^{\circ} \mathrm{E}, \mathrm{N} 30^{\circ} \mathrm{E}$ and $N 20^{\circ} \mathrm{W}$ trending faults. On the well-preserved volcano of Nisyros the architecture of the volcanic edifice has significantly been affected by 'trap-door' volcanotectonics of a major volcanic infrastructure in the area namely the Kos-Caldera.
\end{abstract}

Key words: volcanotectonics, trapdoor, apical graben, Kos-Datca Graben.

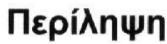

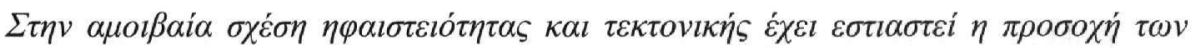

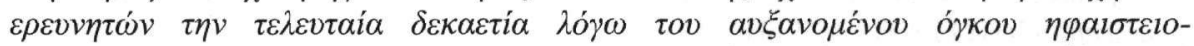

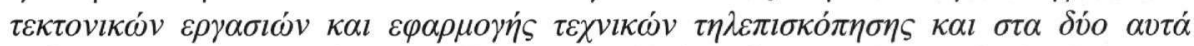

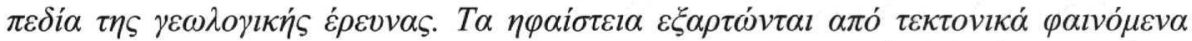

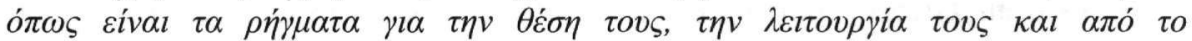

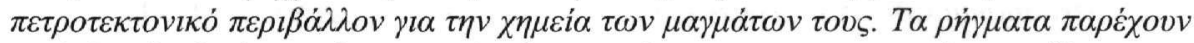

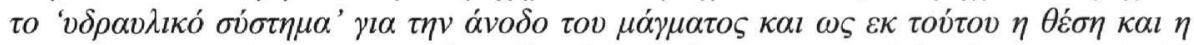

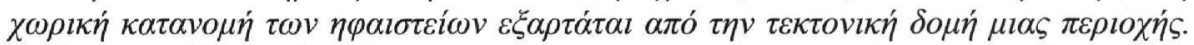

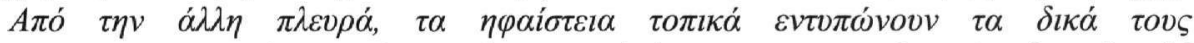

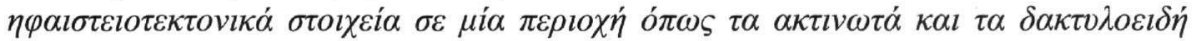




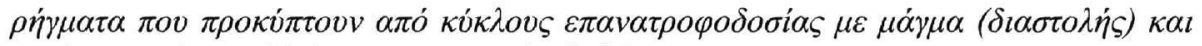

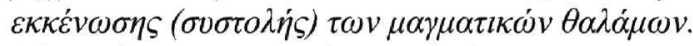

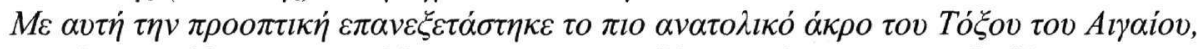

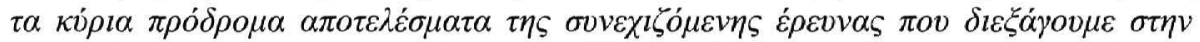

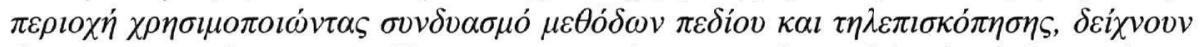

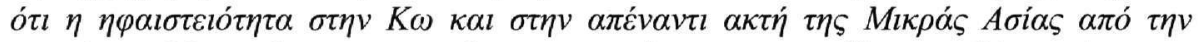

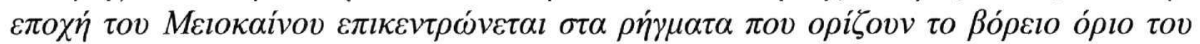

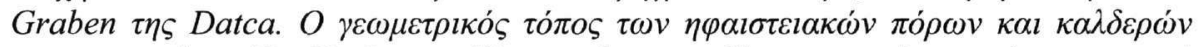

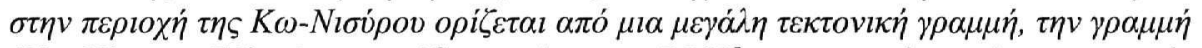

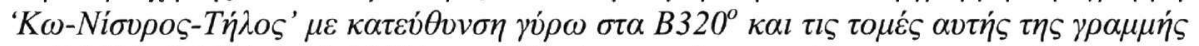

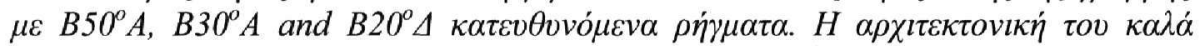

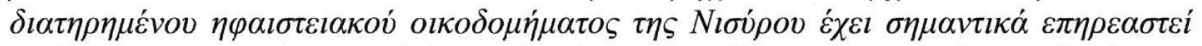

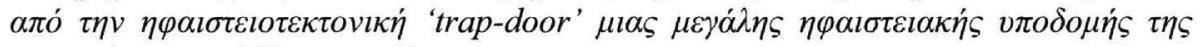
$\pi \varepsilon \rho \imath \propto \chi \dot{\eta} \varsigma, \tau \eta \varsigma \kappa \alpha \lambda \delta \dot{\varepsilon} \rho \alpha \varsigma \tau \eta \varsigma K \omega$.

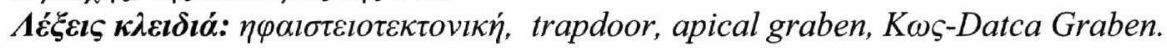

\section{Introduction}

The intimate relationship between tectonics and volcanism has been rather underplayed in scientific works investigating subjects of either discipline. However, where, how and when volcanoes erupt and to a considerable extend what type of volcanic edifice they construct is mainly controlled by their local and regional tectonic framework and the tectonic-volcanic forces active within it. The basic prerequisite for magma to rise to the surface is a conduit, provided by a discontinuity such as a fault; it is within this perspective that the field of volcanotectonics has developed at a very fast rate in the last decade.

In this paper, we will try to show, using the example of Nisyros volcano, how the tectonicvolcanic elements i.e. the fault systems of this stratovolcano relate to the volcanic-tectonic elements such as apical block protocalderas, trapdoor calderas and feeder systems of Nisyros and of the larger area (Kos-Nisyros volcanic complex) and the conjugate history of evolution of volcanism-tectonism in the overall area of Gokova-Kos Graben since Miocene times.

\section{The Volcanic Stratigraphy of Nisyros}

Nisyros has a structure typical of stratovolcanoes: the non-exposed volcanic stratigraphy displayed in the cores of test drillholes for geothermal energy (P.P.C. unpublished data) consists of intercalations of andesitic lavas with andesitic pyroclastic deposits bound by feeder systems of sills and dykes of similar composition. The exposed stratigraphy begins with pillowed basaltic andesite and pillow breccia and evolves towards more felsic volcanism with rhyodacitic post-caldera domes at the end (St. Seymour 1996). The more recent caldera is a well-defined circular topographic feature with a diameter of $4 \mathrm{~km}$, a presently flat caldera floor intercepted by phreatic craters characterized by a drop in the order of $\sim 300 \mathrm{~m}$. The highest point is the top of the St. Helias post caldera dome (698 m) (Fig. 1). The oldest age in the exposed stratigraphy is $\sim 160.000$ years (Di Paola 1974) and the most recent phreatic eruption took place in 1867 A.D. (Marteli 1917). The recent calderaforming eruption created a tephra dated c.a. 46.000 yrs BP equivalent to the $\mathrm{Y} /$ tephra horizon identified in sea sediments (Margari 2004).

Mapping of the volcanic stratigraphy comprising 10 units was initially done by Di Paola (1974) and more detailed work was done more recently by Vougioukalakis (1989) establishing 24 units. In this paper we separate these 24 units into four cycles using combined analysis of volcanic stratigraphy along with structural observations. The volcanic stratigraphy of Nisyros shown in Figs 1,3 is simplified according to the tectonic elements which appear to govern the emplacement and exposure of volcanic products in three dimensions during the evolution of the volcano. 


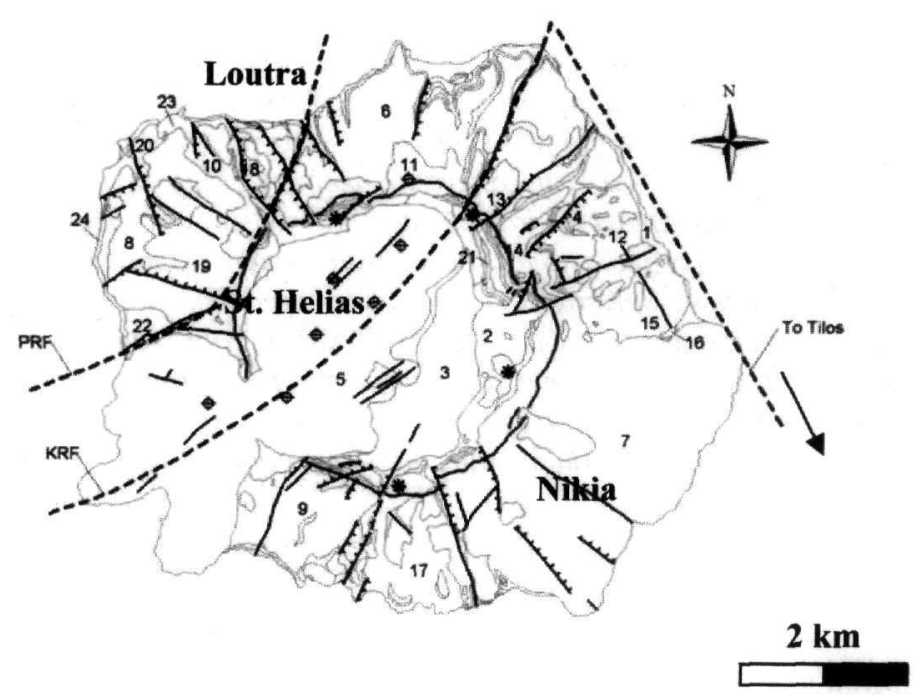

Figure 1 - Geological map of Nisyros island (Modified after Vougioukalakis 1989): Circles embounding cross indicate the highest points of rhyodacitic post-caldera domes (see St. Helias), Stars indicate remnants of feeder systems (volcanic necks) and tick-lines represent local grabens (see Nikia-Loutra Graben). Dashed lines KRF (Kos Ring Fault) and PRF (Perigussa Ring Fault) represent the 'sagging fault' and 'trapdoor fault' respectively and the main northwesterly trending fault zone to Tilos island. The volcanic stratigraphy is indicated by numbers (1-24) which are explained on the stratigraphy column on Fig. 3

\section{Nisyros Volcano Fault Systems}

\subsection{Regional Tectonic Elements}

Our fault array data (Fig. 2), recent geological structure of the volcano and remote sensing data of other workers have identified four major and two secondary fault systems on the Kos-Nisyros-Yali area (Papanikolaou et al. 1991, Vougioukalakis 1993, Papanikolaou and Nomikou 2001, Lagios et al. 2005).

- Major Fault Systems

I. The $f 1$ fault system trends in a northeasterly direction $\left(\mathrm{N} 50^{\circ} \mathrm{E}\right.$, Fig. 2) with an easterly subvertical dip $\left(70^{\circ}-80^{\circ}\right)$ and a maximum throw at $100 \mathrm{~m}$. This is part of the horstgraben structure that passes from Kandeliousa-Yali-Datca Peninsula.

II. The $f 2$ fault system trends at $\mathrm{N} 30^{\circ} \mathrm{E}$, i.e. it is rotated $20^{\circ}-25^{\circ}$ counter-clockwise relative to f1 it dips subvertically $\left(70^{\circ}-80^{\circ}\right)$ westerly-northwesterly and displays a maximum throw of $\sim 120 \mathrm{~m}$. These faults have been traced also in the boreholes for geothermal energy on the caldera floor.

III. The $f 3$ fault system trends at $\mathrm{N} 40^{\circ} \mathrm{W}$ or $\mathrm{N} 320^{\circ}$ and dips subvertically. It is a major fault system which has localized many of the main volcanic vents in the area (St. Seymour et al. 2006a). Its trend runs from easterly Tilos, Nisyros through the volcano of Yali and into Kos island and parallel to it from the NW part of Tilos, crosscuts the island of Nisyros along the western part of Yali and runs into Kos island (Fig. 7). This is a longlived fault system affecting on Nisyros pre-caldera, as well as, post-caldera lithologies. It has extensional characteristics with downfaulted displacements reaching $70 \mathrm{~m}$ and subvertical dips $\left(70^{\circ}-80^{\circ}\right)$ change along its strike. The $f 3$ fault system can be related to the $f 4$ fault system by a $20^{\circ}-25^{\circ}$ counter-clockwise rotation. 

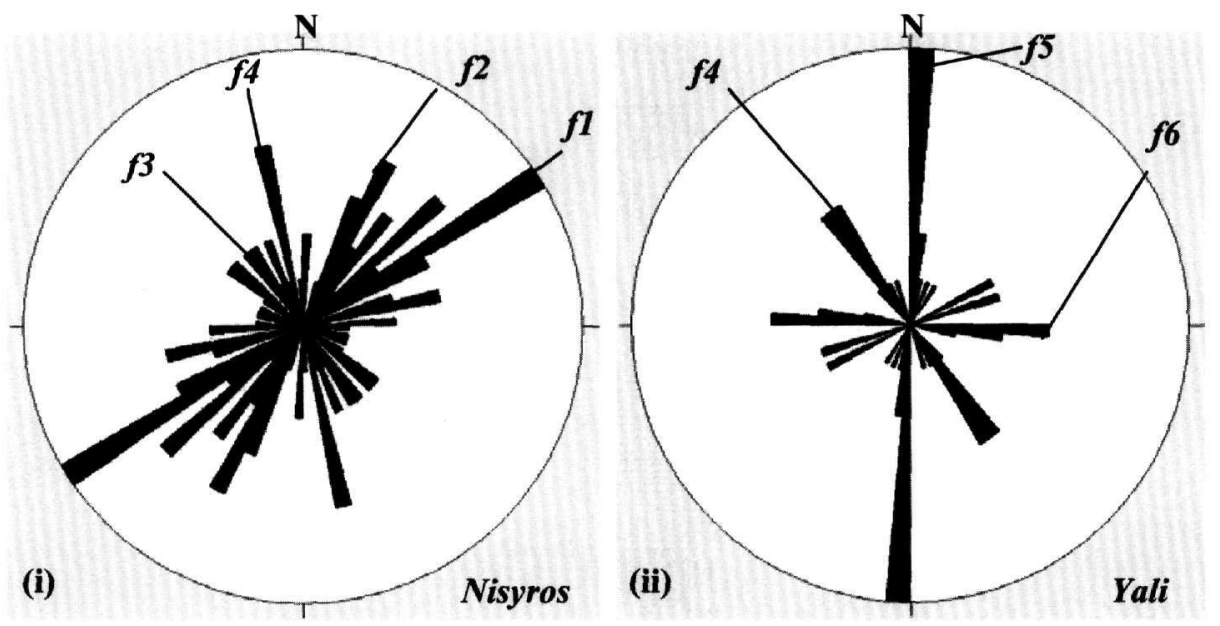

Figure 2 - Rose diagrams of Nisyros (i) and Yali (ii) islands: Four major tectonic systems (f1, $f 2, f 3$ and $f 4$ ) and a radial fault system are clearly displayed on Nisyros island. Two secondary fault systems are visible on Yali island which might represent the conjugate sets of $f 1$ and $f 2$ fault systems. ( $i-50$ classes $/ n=60, i i-50$ classes $/ n=30)$

IV. The $f 4$ fault system comprises major faults trending $\mathrm{N} 20^{\circ} \mathrm{E}$ or $\mathrm{N} 340^{\circ}$ and $\operatorname{dip} 70^{\circ}-80^{\circ}$ towards the west and east forming that way horst-graben structures on the volcano of $\mathrm{Ni}$ syros. Strands of these faults begin from the Stefanos phreatic crater and extend to the southeast resulting in a graben depression characterised by throws in the order of 40-50 $\mathrm{m}$ drop (Fig. 1; Nikia region).

- Secondary Fault Systems

V. The $f 5$ fault system and

VI. The f6 fault system might represent the conjugate sets of $\mathrm{f} 1, \mathrm{f} 2$ fault systems. Our data show a preponderance of $\mathrm{f5}, \mathrm{f} 6$ on Yali. Lagios et al. (2005) based on bathymetry report a N-S oriented graben between Yali and Strongyli and in the Kefalos peninsula of Kos.

\subsection{Volcanotectonic Elements}

On the 'rose-diagram' of Fig. 2 the volcanotectonic element of Nisyros island are clearly displayed. These consist mainly of the caldera radial faults with directions spanning $0^{\circ}$ to $360^{\circ}$ of the Rosediagram. The $\mathrm{f} 1\left(\mathrm{~N} 50^{\circ} \mathrm{E}\right)$ and $\mathrm{f} 3\left(\mathrm{~N} 40^{\circ} \mathrm{W}\right.$ or $\left.\mathrm{N} 320^{\circ}\right)$ faults on the northern part of Nisyros island are tangential and bounding to the Perigussa Ring Fault (PRF) 'trapdoor fault' discussed here (Fig. 1). Horizontal and vertical deformation along this fault and clear definition of it because of the applied colour contouring for vertical displacement in Figure 4 of Lagios et al. (2005). The other major volcanotectonic feature related to the ring fault of the Kos depression/sagging (St. Seymour et al. 2006a) is marked as Kos Ring Fault (KRF) on Fig. 1.

\section{Fracturing during volcanic activity: Magma ascent and formation of proto-caldera - caldera system}

Doming over an inflated subvolcanic magma chamber produces an apical flattening and subsequently a polygonal apical graben (Fig. 4) i.e. a protocaldera (Komuro 1987, Marti et al. 1994, Walter and Troll 2001). The intrusion of magma through fractures (conduits) produces inflation of the overlying surface and extension of the conduits along the fault planes as dykes propagating in a radial mode. This results in the creation of radial faults, subordinate concentric (ring) reverse faults, sub-perpendicular to the radial faults, followed by encircling or horse-shoe 


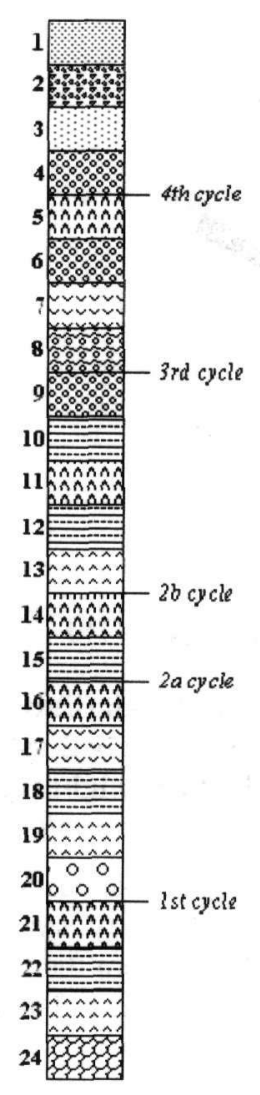

Figure 3 - The volcanic stratigraphy of Nisyros volcano and the four major volcanic cycles indicated by the presence of felsic volcanics at the top of each of the four volcanic cycles: 24submarine andesitic lavas and pyroclastics, 23-lower andesite lava flows, 22-lower basic pyroclastics, 21-lower dacite lava flows $\left(I^{\text {st }}\right.$ cycle $)$, 20-Kastro conglomerate, 19-middle andesite lava flows, 18-middle basic pyroclastics, 17 -middle rhyolite domes and lava flows of Avlaki, 16-dacite lava flows of Pachia Ammos ( $2 a \mathrm{cycle}$ ), 15-Pyroclastic formation of Panayia Kyra, 14-dacite lava flows rich in inclusions ( $2 \mathrm{~b}$ cycle), 13-upper andesite lava flows, 12upper basic pyroclastics, 11-dacite domes and lava flows of Emporios, 10-block and ash flows of Emporios domes, 9-lower pumice unit ( $3^{\text {rd }} \mathrm{cycle}$ ), 8-reworked lower pumice, 7-domes and lava flows of Nikia rhyolite, 6-upper pumice unit, 5-post-calderadacite domes and lava flows $\left(4^{\text {th }} \mathrm{cycle}\right)$, 4-upper pumice of Yali, 3-hydrothermal explosion products and lacustrine intracalderic deposits, 2-scree and tectonic breccias, 1-beach deposits

shaped faults (Fig. 5). The horse-shoe shaped faults define the apical graben which usually has a mean diameter approximately half of that of the subvolcanic reservoir (Walter and Troll 2001). Due to the strongest extension occurring in the apical graben, slumping of large blocks and subsidence takes place which may produce pressure jumps in the underlying magma chamber triggering large scale ash-flow eruptions (Gudmundsson 1998). The intersection of radial faults with the edges of the apical block, which represents the imprint of the pressure of the upper part of the magma chamber, define the conduits for magma ascent, extrusion to the surface and initiation of erection of the volcanic edifice. Continuation of the volcanic activity will cause a moderate evacuation of the magma chamber and subsidence due to a combination of apical graben displacement and ring-fault subsidence. The caldera ring-fault is a bell shaped fault with a diameter ca. 1.5 times larger than the diameter of the apical block for shallow magma chambers (Fig. 5). Sagging produces wedges in the outermost periphery and an arrangement of subhorizontal faults above the magma chamber followed by steep bell-shaped (main) ring-faults 
(Walter and Troll 2001). During resurgence existing radial faults reopen, supplementary steepening occurs, peripheral faults close due to magma chamber volume increase and reactivation of ring faults results in additional fracturing. Faults may remain active during and following magma chamber evacuation until their expression reaches the surface, implying that collapse subsidence is (i.e. caldera formation) slightly delayed. In conclusion, magma chamber inflation results in radial fractures and dyke injection, an expansion of the flanks and an apical block (protocaldera). Evacuation collapse is characterized by outward-dipping ring faults whilst widespread radial structures are not formed at this stage. Multistage caldera volcanoes are recognized by a network of intersecting radial and concentric structures (dykes and faults) in the central caldera basin and the caldera's periphery. Peripheral relaxation during evacuation forms circumferential en echelon faults in normal and reverse sense and horst and graben structures in-between (Walter and Troll 2001; Fig. 5).

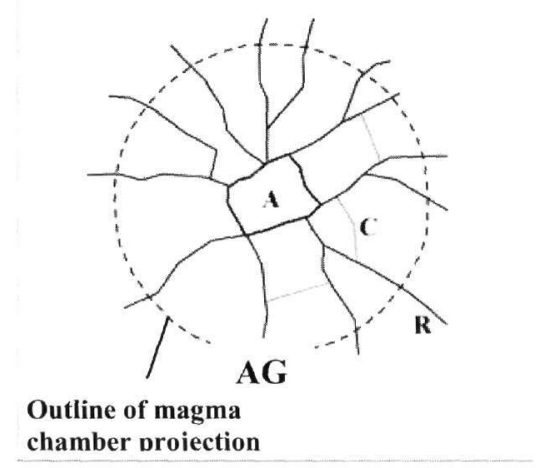

Figure 4 - Ground plan of doming over an inflated subvolcanic magma chamber producing a polygonal apical graben (AG), radial faults (R) and concentric (ring) reverse faults (C) adapted from Walter and Troll, 2001. Dashed line indicates the outline of magma chamber projection on surface

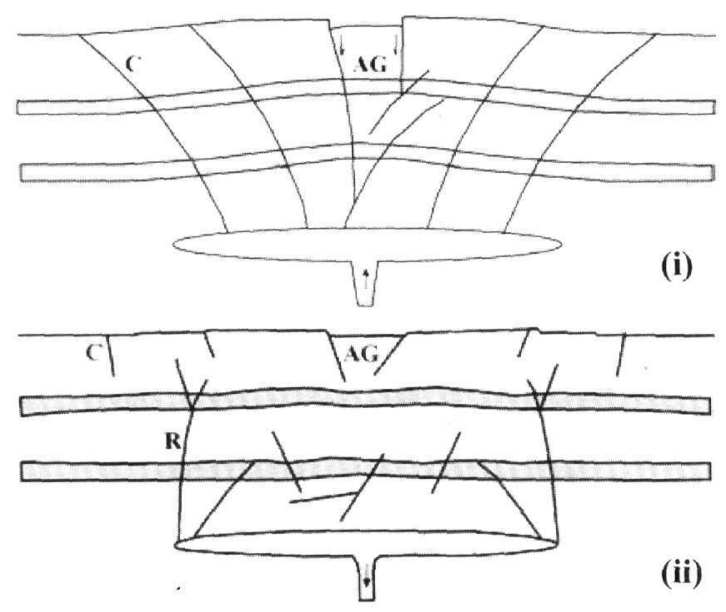

Figure 5 - Fracturing during inflation (i) and evacuation (ii) of the magma chamber adapted from Walter and Troll, 2001. Inflation (i) results in the creation of radial faults, concentric (ring) reverse faults $(C)$ followed by horseshoe-shaped faults. The latter define the apical graben (AG). Evacuation (ii) of the magma chamber results in the creation of a bell-shaped fault (caldera ring fault - $\mathbf{R}$ ) and circumferential en echelon faults in normal and reverse sense and horst-graben structures in between. Arrow indicates the feeder (i) or the evacuation system (ii) 


\section{Volcanotectonic Evolution of Nisyros Volcano}

Test drilling for geothermal energy investigation in the 1980's indicated the presence of a subvolcanic magma chamber under the caldera of Nisyros, hosted in the limestone, at a depth of c.a. 2 $\mathrm{km}$ from the caldera floor (P.P.C. unpublished data).

\subsection{Andesitic Stratocone Proto-Caldera}

The Nisyros protocone consisted of pillowed basaltic andesite and andesite in the form of subaqueous pillow lavas and hyaloclastites succeeded by massive flows, dykes, sills and mafic pyroclastic rock of andesitic composition (St.Seymour and Vlassopoulos 1991).

Since the present caldera is the topographic expression on the ground of the partly evacuated subvolcanic magma chamber we will extrapolate the argument that the topography of the first subaerially emerged andesitic stratocone (proto-Nisyros) reflected mainly the volcanotectonic elements propagated by inflation-magma feeding-deflation and partial magma chamber collapse cycles. Inflation of magma chamber resulted in a radial fault network on the crust overlying the magma chamber and an apical block due to maximum extension at its center. Intrusion of magma through fault planes would create radial and reverse concentric (ring) faults, as well as, horseshoe-shaped faults (Fig. 5).

Feeders for the erupted materials of andesitic basaltic andesite composition would lie in the intersections of the major apparently regional northeasterly fault systems with volcanotectonic elements such as radial and concentric faults or apical block borders. Intersection of these conduits would assume initially the simplified 'star shape' forms shown in Fig.6. Furthermore lubrication, inflation and partial erosion and widening of the leading faults (conduits) by the ascending magma can endeavour more the role of fault intersection. As mentioned above, this whole fault and apical block geometry would also be imprinted on the Nisyros protocone and the localization of its feeder systems. Remnants of one of these feeders (andesitic volcanic neck) has been unroofed in the north-northwestern part of the caldera floor near the caldera wall (Fig. 1) and probably represents the intersection of a radial fault with an apical block boundary. Partial evacuation of the magma chamber would have formed a proto-caldera due to a combination of apical graben displacement and ring fault subsidence. From the location of this neck and assuming that the size of Nisyros magma chamber remained more or less the same over the last $\sim 160.000$ years, we can calculate the size and location of the Nisyros proto-caldera suggesting also locations of other, similar to the aforementioned, feeder systems (volcanic necks) (Fig. 1). That is, a caldera diameter represents almost half the diameter of the magma chamber and if the main ring fault is 1.5 times larger than the diameter of the apical block then the proto-caldera of the Nisyros cone was 2-2.6 km in width and was located in the northwestern portion of the present caldera and near the inner caldera wall (Fig. 1). Tilting or slumping of the apical block could produce pressure jumps in the magma chamber, localized concentration of volatiles and ash-flow, (in the case of Nisyros 'scoria-flow' eruptions) (Gudmundsson 1998). This might be related to the emplacement of the lower and middle mafic pyroclastic formations (Figs 1,3). Periodic closing and stagnation of the magma chamber is indicated by the presence of felsic volcanics at the top of each of the four volcanic cycles (from mafic to felsic) indicated in the volcanic stratigraphy of Nisyros (Fig. 3). Progressive stagnation of the system is reflected by the increase in the volume of felsic volcanic products in the upper two cycles. Opening of the chamber and ensuing magma mixing between resident andesitic and felsic magma end-members is indicated by the presence of dacite in the uppermost position of the volcanic cycles (St. Seymour and Vlassopoulos 1989) (Fig. 3).

\subsection{The precursor caldera}

On the Nisyros 1:25.000 geological map by I.G.M.E. (Vougioukalakis 1989) (Fig. 1) the feeder necks of units 19, 17, 11, 7 and also the feeder system of unit 6 (St. Seymour unpublished data) are closely proximal to the bounding ring fault of the recent caldera. Since these units are emplaced at 
times which cover the total time spectrum in which the subaerial edifice was built, we propose here that this bounding ring fault was long-lived. Since for shallow chambers, as that of Nisyros, the position of the chamber beneath the surface influences the distribution of all concentric structures, bounding ring fault included (Roche et al. 2000), we propose that the Nisyros subvolcanic chamber occupied a rather permanent position and therefore the precursor caldera or calderas of Nisyros were occupying the same position. The geometries of these calderas might have been different to accommodate than the recent caldera geometry, taking into account the effects of edifice morphology indicated by the experiments of Walter and Troll (2001).

\section{A 'Bird's Eye View' of Nisyros: The effect of Kos Trap-door Caldera Tectonics}

St Seymour et al. (2006a) and Zouzias and St. Seymour (2006) have given an interpretation of volcanic depressions (calderas) in the Kos-Nisyros area, the localization of which results from the intersection of a major tectonic line intercepting the east coast of Tilos, Nisyros, Yali and passing through Kos with other major crustal discontinuities such as the western extension of the Gòkova Graben (Fig. 7). In figure 7 the larger structure, an approximately $20 \mathrm{~km}$ partly submerged caldera, represents the caldera of the 160.000 yrs major eruption of the Kos Plateau Tuff (KPT) and this closely coincides with the interpretation given by Allen (2001) based on physical volcanology arguments. The southeastern portion of the bounding ring faults of the KPT caldera (KRF; Fig. 1) and Perigussa depression (PRF; Fig. 1) cut the western and central part of the Nisyros edifice (Fig. 1). We will discuss here the effects of these volcanotectonic features on the evolution of Nisyros volcanic edifice. Both of these faults seem to follow the general tectonic NE-SW direction, however, since they represent arcs of large extensive bounding ring faults the are gently curved towards the northwest (Fig. 7).

\subsection{The effect of Perigussa Ring Fault (PRF) on the Nisyros Edifice}

- The intersection of this fault with the bounding fault of the apical block of proto-Nisyros and/or with a radial fault could have provided the passageways necessary (Fig. 6) for the ascent of the andesitic magma which erected the subaerial portion of the Nisyros stratocone.

- 'Trap-door' rotating motion on the PRF could alternatively submerge or emerge the northwestern portion of the island. Such a rotating motion has presently emerged basaltic andesite pillow lavas and pillow breccias under the old castle wall near Mandraki. Submerging motion in the past would account for the lack of units at the high and medium positions of the volcanic stratigraphy, resulting in exhumation and exposure of unit 19 which has constructed the main body of the subaerial Nisyros protocone.

In multistage caldera volcanoes peripheral relaxation forms circumferential en-echelon faults in normal and reverse sense and horst and graben structures (Walter and Troll 2001), a few of which are indicated in Fig. 5. Rotation and submergence of the northwestern part of the island and inundation of the local grabens (Fig. 1) would account for the fault-bound exposures and reworking by water of the pumices of unit 8 and the fault-bound conglomerate of unit 20 .

\subsection{The Effect of the KPT Ring Fault on the Nisyros Edifice}

This is a long-lived structure which appears to intersect the subvolcanic magma chamber of Nisyros since it has provided the more efficient feeder passageway for the emplacement of the six postcaldera dacite-domes of Nisyros (unit 5), than the recent caldera bounding ring fault (Fig. 1). A casual examination may identify this portion of the KPT ring fault as a simple regional tectonic northeasterly structure; however, upon closer examination of the spatial distribution of the apices of the six domes of unit 5 and the apex positioning of the dome of unit 11 may reveal its westerly curvature. 

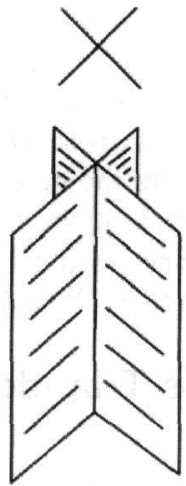
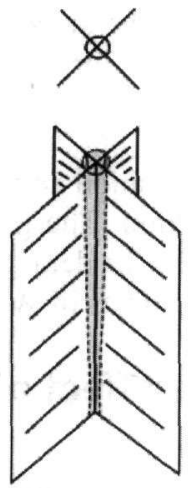
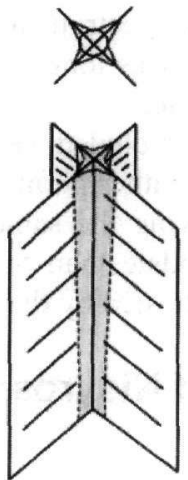
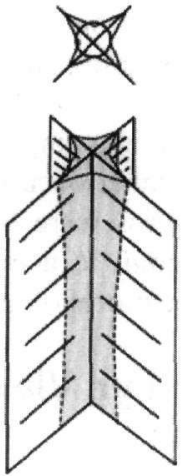

Figure 6 - Intersection of leading faults providing conduits which would assume initially the simplified 'star shape' form due to inflation and partial erosion and widening of these leading faults. The intersection of these faults with the bounding faults of the apical block of the proto-caldera and/or with radial faults could provide passageway for magma to ascent

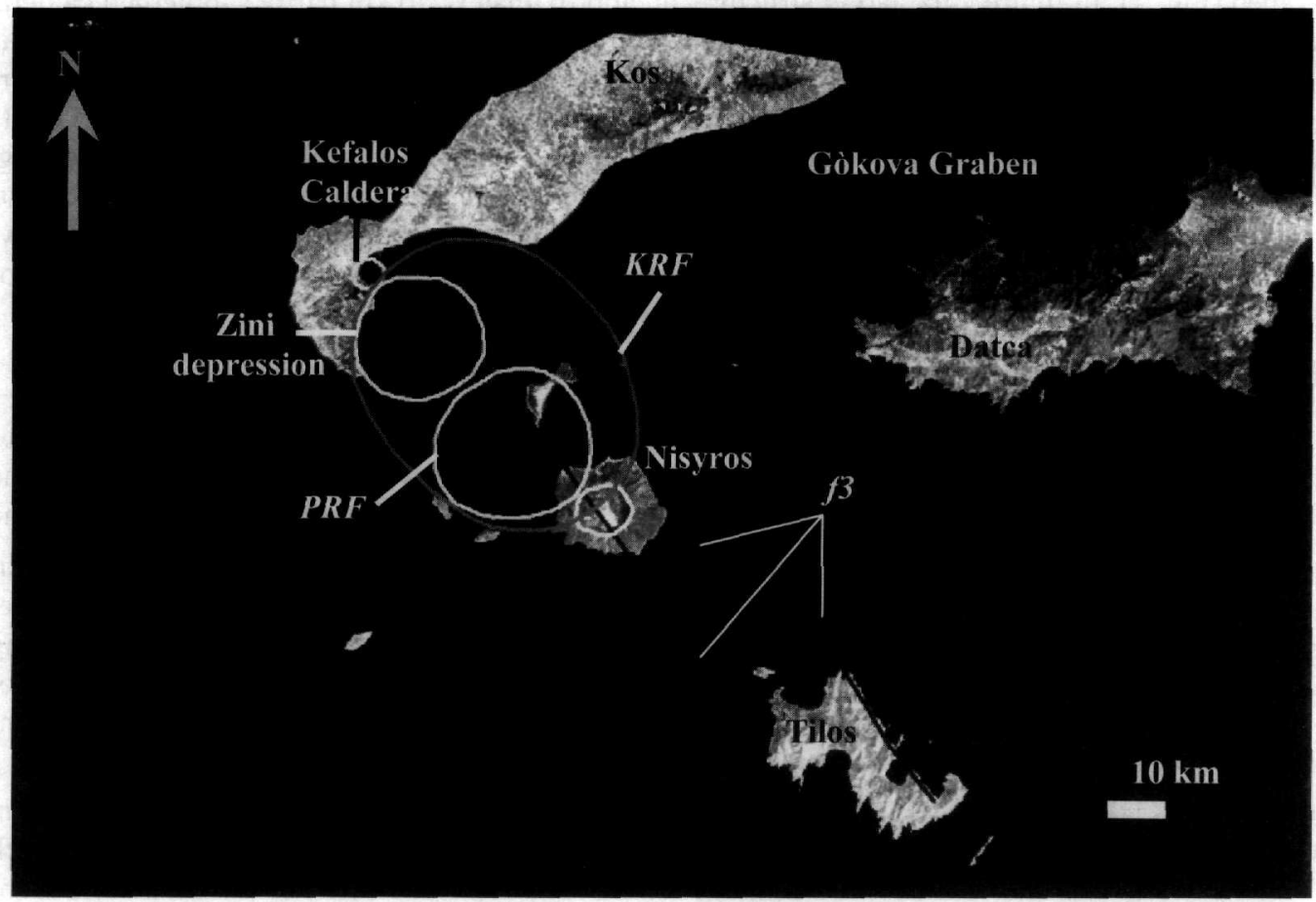

Figure 7 - Landsat-TM image of Kos-Yali-Nisyros-Tilos-Datca area. The $f 3$ fault system localizes the main volcanic centers of the area characterized of major discontinuities such as the Gòkova Graben. The KRF and the PRF faults seem to follow the general tectonic NE-SW direction, representing ares of large extensive bounding ring faults. An interpretation of volcanic depressions (calderas) in the Kos-Nisyros caldera complex is shown, such as Nisyros caldera, Kefalos caldera, Zini and Perigussa depressions, hosted in the sagging caldera of Kos (St. Seymour et al. 2006)

The formation of Panayia Kyra entails many surge deposits which indicate infusion of moisture in the magmatic conduit system. It can be speculated for Panayia Kyra surges may have been located in the Nikia-Loutra Graben (Fig. 1) which has presently confined the positions of all the phreatic craters in the recent caldera floor. We trust, that the doctoral research presently underway 
investigating this formation (Vougioukalakis personal communication 2006), will provide definite answers to the above considerations.

\section{Evolution of volcanism in the Gòkova-Kos Graben}

Submarine active tectonism in the southeastern Aegean Sea-southwestern Anatolia (Gulf of Gòkova, reported here as Gòkova-Kos Graben) was investigated by Kurt et al. (1999) with multichannel seismic reflection methods. These workers concluded that the opening of the graben was initiated in late Miocene. Boger (1978) reports that normal faults commencing in Late Miocene on Kos island may heralt the opening of the Gòkova-Kos Graben. The southern part, towards the mouth of the graben is bound by a major east-west trending listric fault, the Datca Fault, whereas an antithetic, major, normal fault defines the northern boundary of the graben. However, due to its low dip angle the Datca Fault was decelerated since Early Pleistocene and continuing extension was uptaken by the faults in the northern boundary of the Gòkova Gulf which shows high seismic activity even in the Present. A moderate earthquake in 1968 (magnitude 5.5) in the gulf south of Kos island is attributed to this fault array (Kurt et al. 1999). We propose here that the intersection of the continuation of these faults in the Kos-Nisyros area with major northwesterly faults such as the 'Tilos-Nisyros-Kos' Fault have provided access for magma ascent and volcanism in the area.

\section{Acknowledgments}

We would like to thank Dr. Ioannis Koukouvelas for the review of an early version of this work and Dr. George Vougioukalakis for the scientific discussions on the volcanology of Nisyros.

\section{References}

Allen, S.R., 2001. Reconstruction of a major caldera-forming eruption from pyroclastic deposit characteristics: Kos Plateau Tuff, eastern Aegean Sea, J. Volcanol. Geotherm. Res., 105, 141-162.

Boger, H., 1978. Sedimentary history and tectonic movements during the late Neogene. In H. Closs, D. Roeder and K. Schmidt (eds), Alps, Appenines, Hellenides, Schweizerbart, Stuttgart, 225-255pp.

Di Paola, G.M., 1974. Volcanology and petrology of Nisyros island (Dodecanese, Greece), Bulletin of Volcanology, 38, 944-987.

Gudmundsson, A., 1998. Formation and development of normalfault calderas and the initiation of large explosive eruptions, Bull Volcanol, 60,160-170.

Komuro, H., 1987. Experiments on cauldron formation: a polygonal cauldron and ring fractures, $J$ Volcanol Geotherm Res, 31,139-149.

Kurt, H., Demirbag, E., and Kuscu, I., 1999. Investigation of the submarine active tectonism in the gulf of Gokova, southwest Anatolia-southeast Aegean Sea, by multi-channel seismic reflection data, Tectonophysics, 305, 477-496.

Lagios, E., Sakkas, V., Parcharidis, Is., and Dietrich, V., 2005. Ground deformation of Nisyros volcano (Greece) for the period 1995-2002: Results from DInSAR and DGPS observations, Bull Volcanol, 68, 201-214.

Margari, V., 2004. Late Pleistocene vegetational and environmental changes on Lesvos Island, Greece, Ph.D. 663 Thesis, University of Cambridge, Cambridge, UK.

Martelli, A., 1917. Il gruppo eruttivo di Nisyros nel mare Egeo, Mem. Soc. Geol. Ital. Sc. (detta dei $X L$ ), Serie $3 \mathrm{a}$, vol. XX. 
Marti, J., Ablay, GJ., Redshaw, LT., and Sparks, RSJ., 1994. Experimental studies of collapse calderas, J Geol Soc London, 151, 919-929.

Papanikolaou, D., Lekkas, E., and Sakellariou, D., 1991. Geological structure and evolution of Nisyros volcano. Bulletin of the Geological Society of Greece, XXV/1, 405-419.

Papanikolaou, D., and Nomikou, P., 2001. Tectonic structure and volcanic centers at the eastern edge of the Aegean volcanic arc around Nisyros island, Bull Geol Soc Greece, XXXIV, 12891296 pp, Proc. $9^{\text {th }}$ Intern. Congress, Athens, Sept. 2001.

P.P.C., unpublished data, 1982. Geology and petrography report on the Geothermal Well NISYROS 1 and Petrography Report on the Geothermal Well NISYROS 2 by Vichos G. and Chlaboutakis $\mathrm{M}$.

Roche, O., Druitt, T., and Merle, O., 2000. Experimental study of caldera formation, $J$ Geophys Res, 105, 395-416.

St. Seymour, K., and Vlassopoulos, D., 1989. The potential for future explosive volcanism associated with dome growth at Nisyros, Aegean volcanic arc, Greece, J. Volcanol. Geother. Res., $37,351-364$.

St. Seymour, K., and Vlassopoulos, D., 1991. Magma Mixing at Nisyros volcano, as inferred from incompatible trace-element systematics, Journal of volcanology and Geothermal Research, 50, 273-299.

St. Seymour, K., 1996. Geochemistry of the Yali volcano rhyolites and their relationship to the volcanic products of Nisyros, Aegean volcanic arc, N. Jb. Miner. Mh., H.2, 57-72.

St. Seymour, K., Kouli, M., Zouzias, D., Papaioannou, G., and Vamvoukakis, C., 2006a. Identifying Calderas in Aegean Sea, Hellas, Using Remote Sensing Techniques, European Congress on Regional Geoscientific Cartography and Information Systems Earth and Water, $13^{\text {th }}$ June 2006, Barcelona, Spain.

St. Seymour, K., unpublished data. Localization of the feeder intersection point of the Upper Unit Pumices on Nisyros Volcano.

Vougioukalakis, G., 1993. Volcanic stratigraphy and evolution of Nisyros island, Bull. Gel. Soc. Greece, 28 (2), 239-258.

Vougioukalakis, G., 1989. Geologic map of Nisyros island. 1:25,000, IGME.

Walter, TR., and Troll, VR., 2001. Formation of caldera periphery faults: an experimental study, Bull Volcanol, 63, 191-203

Zouzias, D., and St. Seymour, K., 2006. Geochemical Evidence for the Coeval Relationship of the Kos Plateau Tuff (KPT) and Tilos Pumices, Aegean Volcanic Arc, Greece, Submitted in Neues Jahrbuch für Mineralogie. 